\title{
Aktivitas Trypsin Inhibitor Berbagai Varietas Biji Kedelai (Glycine max L.) dan Perubahannya Selama Perkecambahan Biji dari Varietas Terbaik
}

\author{
Trypsin Inhibitor Activity of Some Soybean (Glycine max L.) Varieties and its Change \\ during Seed Germination of the Best Variety
}

\author{
Bayu Kanetro ${ }^{1 *}$, Zuheid Noor $^{2}$, Sutardi $^{2}$, Retno Indrati ${ }^{2}$ \\ ${ }^{1}$ Staf Pengajar Fakultas Teknologi Pertanian Universitas Wangsa Manggala Yogyakarta \\ Jl.Wates Km 10 YogyakartaE-mail: bayu_kanetro@yahoo.co.id *Penulis untuk korespondensi \\ ${ }^{2}$ Staf Pengajar Jurusan TPHP Fakultas Teknologi Pertanian UGM Yogyakarta
}

\begin{abstract}
This study investigated the activity of trypsin inhibitor (TI) of some soybean (Glycine $\max$ L.) varieties and the change in TI activity during seed germination of the best variety. The research was aimed to determine the best variety of soybean and germination time based on the highest TI activity. There were 5 varieties of soybeans, Paderman, Argomulyo, Kaba, Sinabung, and Ijen. The best variety of soybean was Sinabung as shown by the highest TI activity. The soybean of Sinabung variety was germinated for 6 various germination times at 12, 24, 36, 48, 60 and 72 hr. The result showed that the variation of germination time changed TI activity. TI activity decreased significantly after $36 \mathrm{hr}$ of germination of soybeans. The best time of germination was $36 \mathrm{hr}$.
\end{abstract}

Key words: Soybean varieties, germination, trypsin inhibitor activity

Diterima: 26 Agustus 2006, disetujui: 12 Desember 2006

\section{Pendahuluan}

Trypsin inhibitor (TI) adalah senyawa yang apabila ditambahkan dalam campuran enzim tripsin dan substrat akan berfungsi mengikat enzim dan menurunkan kecepatan pemecahan substrat (Liu, 1999). Senyawa ini yang sebelumnya merupakan zat anti gizi dan tidak bermanfaat, ternyata termasuk kelompok phytochemical yang merupakan komponen bioaktif dengan kemampuan sebagai anticarcinogenic, yaitu jenis TI Bowman-Birk (Kennedy, 1998 dalam Losso, 2002). Selain itu TI juga merupakan senyawa yang bersifat hipoglisemik, memiliki kemampuan menurunkan gula darah (Zuheid-Noor et al., 2000) sehingga dapat dikembangkan sebagai makanan fungsional bagi penderita diabetes khususnya yang tidak tergantung insulin.

Di Indonesia terdapat berbagai macam varietas kedelai, sebagai contoh di Balai
Penelitian Kacang-kacangan (BALITKABI Malang) menunjukkan ada 5 varietas kedelai, yaitu Paderman, Argomulyo, Kaba, Sinabung, dan Ijen. Kelima varietas tersebut sering mengalami perubahan nama varietas tergantung daerah penyebarannya, misalnya varietas Ijen mengalami perubahan nama menjadi Wilis yang dikenal di Yogyakarta, atau Malabar yang dikenal di Jawa Barat. Terdapat perbedaan spesifikasi varietas-varietas kedelai tersebut baik fisikawi maupun kimiawinya. Kadar protein bervariasi dari $39,5 \%$ (Ijen) sampai $50,5 \%$ (Sinabung). Perbedaan spesifikasi tersebut khususnya kadar protein kemungkinan berpengaruh juga terhadap aktivitas TI, sehingga perlu dilakukan penelitian untuk menentukan varietas kedelai yang memiliki aktivitas TI paling tinggi sehingga tepat digunakan sebagai sumber TI untuk diaplikasikan pada makanan fungsional khususnya bagi penderita diabetes. 
Salah satu kendala untuk mengaplikasikan kacang-kacangan, khususnya kedelai sebagai makanan fungsional bagi penderita diabetes adalah sifat TI yang sebagian besar tidak stabil terhadap pemanasan (Frokier et al., 1997), sehingga kemungkinan akan terjadi penurunan aktivitas TI yang cukup nyata setelah proses pengolahan pangan. Menurut Miyagi et al., (1997) dalam Su dan Chang (2002) produk-produk olahan kedelai mengandung aktivitas TI yang terbatas, yaitu tinggal 0,3 - 13\% dari aktivitas TI biji kedelai segar, sehingga konsumsi produk olahan kedelai bagi penderita diabetes kemungkinan tidak memberikan manfaat penurunan gula darah. Kendala lain adalah, pada umumnya kacang-kacangan khususnya kedelai dalam bentuk biji tidak lazim dikonsumsi pada kondisi segar (belum diolah), karena adanya beany flavor yang tidak disukai. Oleh karena itu perlu dicari jenis-jenis makanan fungsional dari kedelai yang tepat untuk penderita diabetes. Kecambah kacang-kacangan merupakan salah satu alternatif untuk mengatasi permasalahan tersebut. Kecambah kacang-kacangan memiliki aktivitas lipoksigenase yang lebih rendah dibandingkan dalam bentuk bijinya, sehingga dapat mengurangi beany flavor (King \& Puwastien, 1987; Bayu-Kanetro \& Wariyah, 2002). Selain itu konsumsi kecambah kacang-kacangan di Indonesia ternyata lebih tinggi dari pada dalam bentuk bijinya (Wahyuni, 1991 dalam Sutardi, 1996).

Pada umumnya yang dimaksud dengan kecambah kacang-kacangan adalah biji kacangkacangan yang kulit bijinya telah pecah membentuk calon individu baru berwarna putih, belum keluar akar serabut dan calon daun (Sutardi, 1996). Waktu perkecambahan setiap jenis kacang-kacangan bervariasi. Proses perkecambahan kedelai membutuhkan waktu 2-3 hari untuk mendapatkan kecambah yang siap dikonsumsi (Bayu-Kanetro \& Wariyah, 2002). Jenis kecambah yang umumnya dikonsumsi adalah kecambah kacang hijau. Kedelai juga lazim dikonsumsi dalam bentuk kecambah, meskipun tidak sebanyak kecambah kacang hijau. Aktivitas TI kedelai $(15,77 \mathrm{mg}$ inhibitor/g sampel) jauh lebih tinggi dibandingkan kacang hijau (2,37 mg inhibitor/g sampel) dan jenis kacang-kacangan lain (ratarata kandungan TI kurang dari $12 \mathrm{mg}$ inhibitor/g sampel (Saini, 1989). Hal tersebut menunjukkan bahwa kecambah kedelai memiliki potensi yang lebih baik untuk dikembangkan sebagai makanan fungsional bagi penderita diabetes dibandingkan kecambah kacang hijau.

Selama perkecambahan kedelai akan terjadi modifikasi TI khususnya berat molekulnya, sehingga terbentuk jenis TI baru yang identik dengan KTI (Kunitz Tripsin Inhibitor) (Freed \& Ryan, 1978 dalam Rackis \& Gumbmann, 1981). Menurut Bewly dan Black (1983) fungsi TI dalam biji masih diperdebatkan, namun kemungkinan mencakup tiga fungsi, yaitu sebagai cadangan protein yang larut air, sebagai pengendali aktivitas proteinase endogenous, dan sebagai pelindung protein dari serangan extracelluler proteinase yang kemungkinan berasal dari serangga dan mikrobia. Selama perkecambahan akan terjadi degradasi senyawa cadangan dalam biji termasuk protein dan sintesa senyawa baru. Berdasarkan hal tersebut kemungkinan selama perkecambahan akan terjadi perubahan aktivitas TI. Penelitian ini bertujuan untuk menentukan varietas biji kedelai terbaik berdasarkan aktivitas TI tertinggi dan mengetahui perubahan aktivitasnya selama perkecambahan biji kedelai varietas terbaik. Penelitian ini juga bertujuan untuk menentukan lama perkecambahan terbaik berdasarkan aktivitas TI yang paling tinggi, sehingga diharapkan bisa digunakan sebagai bahan pertimbangan dalam pengembangan protein kecambah kedelai yang memiliki aktivitas TI (crude TI) tersebut untuk makanan fungsional.

\section{Metode Penelitian}

\section{Bahan}

Bahan utama penelitian ini adalah biji kedelai varietas lokal yang diperoleh dari Balai benih di BALITKABI Malang, yaitu Paderman, Argomulyo, Kaba, Sinabung, dan Ijen dengan spesifikasi seperti terlihat pada Tabel 1. Bahan-bahan kimia PA dari Merck dan Sigma yang digunakan meliputi $\mathrm{HCl}$, dan $\mathrm{NaOH}$, phosphat buffer, tripsin, buffer glisin-

Biota Vol. 12 (1), Februari 2007 
$\mathrm{HCl}$, dan BAPNA (Na-benzoyl-DL-arginine pnitroanilide).

\section{Peralatan}

Peralatan yang digunakan meliputi peralatan untuk perkecambahan, pembuatan tepung kecambah, dan pembuatan ekstrak kasar TI serta peralatan untuk analisis kimia. Peralatan-peralatan tersebut meliputi nampan, kain, strimin, penyemprot, inkubator, oven, penangas air, "vortex", magnetic stirier, freeze drier, $\mathrm{pH}$ meter, kertas $\mathrm{pH}$, spektrofotometer, sentrifuse, dan alat-alat gelas/kaca.

\section{Cara Penelitian}

\section{Penentuan varietas kedelai terbaik berdasarkan aktivitas TI}

Penelitian ini dilakukan menggunakan rancangan acak lengkap (RAL) dengan perlakuan varietas kedelai (Paderman, Argomulyo, Kaba, Sinabung, dan Ijen). Data yang diperoleh dianalisis varian, bila ada beda nyata dilanjutkan uji berganda Dnucan.

Biji kedelai dari semua varietas tersebut ditepungkan, diekstraksi crude TI (Zuheid Noor et al., 2000) dan dianalisis aktivitas TI dengan Metode Kakade (Alonso et al., 2000). Varietas kedelai yang memiliki aktivitas TI paling besar berdasarkan pengujian statistik dipilih untuk digunakan pada penelitian tahap perkecambahan kedelai

\section{Perkecambahan}

Penelitian ini dilakukan menggunakan rancangan acak lengkap (RAL) dengan perlakuan lama perkecambahan $(0,12,24,36$, 48, 60 dan 72 jam). Data yang diperoleh dianalisis varin, bila ada beda nyata dilanjutkan uji berganda Duncan.

Biji kedelai varietas terpilih sebanyak $700 \mathrm{~g}$ yang telah disortasi dikecambahkan melalui tahap pencucian, perendaman, dan inkubasi. Proses perendaman kedelai dilakukan dalam aquades dengan perbandingan $1: 4$ (semua biji terendam air) selama 8 jam. Biji kedelai yang telah menyerap air selanjutnya ditiriskan dan dibagi 7 bagian. Satu bagian tidak diinkubasi, sedangkan yang 6 bagian masing-masing diinkubasi dalam wadah tersendiri.

Tahap inkubasi dilakukan pada suhu kamar dan RH mendekati 100\%, serta ditempatkan dalam nampan diameter $20 \mathrm{~cm}$ dan tinggi $10 \mathrm{~cm}$ (nampan perkecambahan), seperti pengukus. Nampan ini dibagi dua bagian, yaitu bagian bawah merupakan tempat air, dan bagian atasnya untuk menempatkan biji yang dikecambahkan. Kedua bagian nampan tersebut dibatasi alas berlubang-lubang kecil yang merupakan alas tempat biji yang dikecambahkan. Nampan perkecambahan diisi air sampai bagian alas yang berlubang-lubang. Nampan perkecambahan ditempatkan di atas nampan lain yang berukuran lebih besar dan berisi air, selanjutnya ditutup kain yang mudah menyerap air sampai sisi-sisi kain tercelup air dalam nampan besar. Air akan terserap sehingga membasahi seluruh permukaan kain, sehingga $\mathrm{RH}$ ruangan dalam kain tetap terjaga mendekati $100 \%$.

Tabel 1. Perbedaan sifat fisik kimiawi lima varietas kedelai

\begin{tabular}{lccccc}
\hline \hline \multicolumn{1}{c}{ Spesifikasi } & Paderman & Argomulyo & Kaba & Sinabung & Ijen \\
\hline \hline Hasil (ton/ha) & 2,15 & 1,8 & 2,13 & 2,16 & 2,15 \\
Umur masak (hari) & 85 & 82 & 85 & 88 & 83 \\
Bentuk biji & Lonjong & Lonjong & Lonjong & Lonjong & Lonjong \\
Warna kulit biji & Kuning muda & Kuning & Kuning & Kuning & Kuning mengkilap \\
Berat (g/100 biji) & 18,19 & 18,5 & 10,37 & 10,68 & 11,23 \\
Protein (\% bk) & 41,21 & 39,62 & 48,66 & 50,53 & 39,55 \\
Lemak (\%) & 17,66 & 13,50 & 14,00 & 13,00 & 13,16 \\
Air $(\%)$ & 10,4351 & 9,5323 & 9,5739 & 8,9577 & 7,9087 \\
\hline \hline
\end{tabular}

Sumber: Anonim (2004)

* Hasil analisis di Lab 
Selama inkubasi dilakukan pengambilan sampel setiap 0 (biji kedelai yang direndam 8 jam tanpa diinkubasi) 12, 24, 36, 48, 60 dan 72 jam. Sampel-sampel tersebut dianalisis kadar air, ditimbang, dikeringkan dengan freeze dryer, ditimbang dan ditepungkan. Selanjutnya dianalisis kadar air, dan diekstraksi crude TI. Crude TI yang diperoleh ditimbang dan dianalisis aktivitas TI. Data penimbangan yang diperoleh digunakan untuk perhitungan rendemen perkecambahan dan rendemen ekstraksi, yaitu dengan rumus sebagai berikut:

Rendemen Perkecambahan

$=$ (berat padatan kecambah : berat padatan biji $)$ $\mathrm{x} 100 \%$

Rendemen ekstraksi terhadap kecambah

$=$ (berat padatan crude TI : berat padatan kecambah) x $100 \%$

Rendemen ekstraksi terhadap biji

$=($ rendemen ekstraksi terhadap kecambah $) \mathrm{x}$ (rendemen perkecambahan) x 100\%

\section{Ekstraksi crude TI dan pengujian aktivitas TI}

Ekstraksi crude TI dilakukan dengan cara tepung kedelai disuspensikan dalam aquades (rasio tepung:aquades $=1: 10$ ), selanjutnya diatur $\mathrm{pH} 4$ dengan $\mathrm{HCl} 6 \mathrm{~N}$. Diaduk dengan magnetig stirer selama 30 menit, suhu $40^{\circ} \mathrm{C}$. Suspensi disentrifugasi pada 1500 g, 10 menit. Supernatan dipisahkan, selanjutnya diatur pH 3 dengan HCL $6 \mathrm{~N}$, selanjutnya disentrifugasi lagi pada $1500 \mathrm{~g}, 15$ menit. Residu yang diperoleh dipisahkan, dan dikeringkan dengan freeze dryer (ekstrak kasar TI atau crude TI).Ekstrak kasar TI yang diperoleh ditimbang dan dianalisis aktivitas TI

Analisis aktivitas TI dilakukan dengan cara sampel crude TI ditimbang sebanyak 0,002 $\mathrm{g}$ dan dilarutkan menjadi $25 \mathrm{ml}$ dengan phosphat buffer $\mathrm{pH} 8$ (larutan ekstrak kasar TI konsentrasi $0,008 \%$, berdasarkan orientasi pada konsentrasi ini sudah memberikan penghambatan yang jelas). Diambil $0,2 \mathrm{ml}$ larutan TI, ditambah $0,25 \mathrm{ml}$ larutan tripsin $0,004 \%$, selanjutnya digojok dan diinkubasi selama 5 menit. Selanjutnya diencerkan sampai $1 \mathrm{ml}$ dengan phosphat buffer $\mathrm{pH}$ 8. Ditambah $2,5 \mathrm{ml}$ larutan BAPNA (No-benzoyl-DLarginine p-nitroanilide) $0,001 \mathrm{M}$ yang sudah dipanaskan suhu $37^{\circ} \mathrm{C}$, kemudian segera ditera dengan spektrofotometer pada $410 \mathrm{~nm}$ (menit ke-0). Sampel tersebut diinkubasi selama 30 menit, kemudian ditera lagi dengan spektrofotometer pada $410 \mathrm{~nm}$ (menit ke-30). Dihitung peningkatan absorbansi (abs) sesudah inkubasi 30 menit. Satu unit tripsin didefinisikan sebagai peningkatan absorbansi sebesar 0,01 unit pada $410 \mathrm{~nm}$. Dibuat kontrol (campuran enzim tripsin dan susbtrat BAPNA tanpa penambahan larutan crude TI) dan dianalisis seperti prosedur diatas. Selanjutnya dihitung penghambatan TI (penurunan abs terhadap kontrol), yaitu peningkatan abs kontrol dikurangi peningkatan abs sampel perlakuan. Satu unit aktivitas TI (inhibitor unit/IU) didefinisikan sebagai penurunan absorbansi terhadap kontrol (penghambatan) sebesar 0,01 unit.

\section{Hasil dan Pembahasan}

\section{Aktivitas TI berbagai varietas biji kedelai}

Pengamatan berat crude TI dari proses ekstrasi berbagai varietas biji kedelai menunjukkan bahwa rendemen yang diperoleh berkisar antara $0,71-0,73 \mathrm{~g}$ padatan crude TI/100 g padatan biji (Tabel 2). Data rendemen digunakan untuk menghitung aktivitas TI terhadap berat kering biji.

Tabel 2. Kadar air biji dan rendemen crude TI*

\begin{tabular}{lcc}
\hline \hline Varietas biji kedelai & Kadar air $(\%)$ & Rendemen (g padatan crude TI/100 g biji bk) \\
\hline \hline Padermen & 10,44 & 0,71 \\
Argomulyo & 9,53 & 0,71 \\
Kaba & 9,57 & 0,72 \\
Sinabung & 8,96 & 0,73 \\
Ijen & 7,91 & 0,72 \\
\hline \hline
\end{tabular}

* rata-rata dari 2 ulangan percobaan dan 3 ulangan analisis 
Berdasarkan pengujian statistik menunjukkan bahwa varietas biji kedelai berpengaruh terhadap aktivitas TI. Varietas Sinabung memiliki aktivitas TI yang paling tinggi seperti terlihat pada Tabel 3 dan Gambar 1. Perbedaan aktvitas TI tersebut kemungkinan berkaitan dengan perbedaan kadar protein biji pada berbagai varietas tersebut. TI merupakan salah satu komponen protein biji kedelai yang berfungsi untuk mengatur hidrolisis protein biji dengan mengendalikan aktivitas proteinase, dan melindungi biji terhadap serangan proteinase dari luar yang merusak protein biji misalnya berasal dari serangga dan mikrobia (Bewley dan Black, 1983). Berdasarkan hal tersebut maka makin tinggi kadar protein biji tentunya dibutuhkan pengendali aktivitas proteinase dan pelindung protein biji yang lebih besar. Biji kedelai Varietas Sinabung mengandung kadar protein paling tinggi dibandingkan varietas yang lain seperti terlihat pada spesifikasi biji kedelai (Tabel 1), sehingga aktivitsa TI-nya paling tinggi juga. Oleh karena itu varietas biji kedelai yang dipilih untuk tahap penelitian selanjutnya adalah Sinabung. Varietas biji yang lain tidak diteliti aktivitas TI-nya selama perkecambahan karena penelitian ini diarahkan untuk menghasilkan kecambah kedelai yang memiliki aktivitas TI tinggi, sehingga hanya varitas biji kedelai dengan aktivitas TI paling tinggi yang dipilih.

Tabel 3. Aktivitas TI biji kedelai dari berbagai varietas*

\begin{tabular}{lc}
\hline \hline Varietas Kedelai & Aktivitas TI (IU/mg biji bk) \\
\hline \hline Paderman & $0,93 \mathrm{a}$ \\
Argomulyo & $0,75 \mathrm{a}$ \\
Kaba & $1,26 \mathrm{~b}$ \\
Sinabung & $1,60 \mathrm{c}$ \\
Ijen & $1,35 \mathrm{~b}$ \\
\hline \hline
\end{tabular}

* rata-rata dari 2 ulangan percobaan dan 3 ulangan analisis, notasi huruf yang sama di belakang angka pada kolom yang sama menunjukkan tidak berbeda nyata.

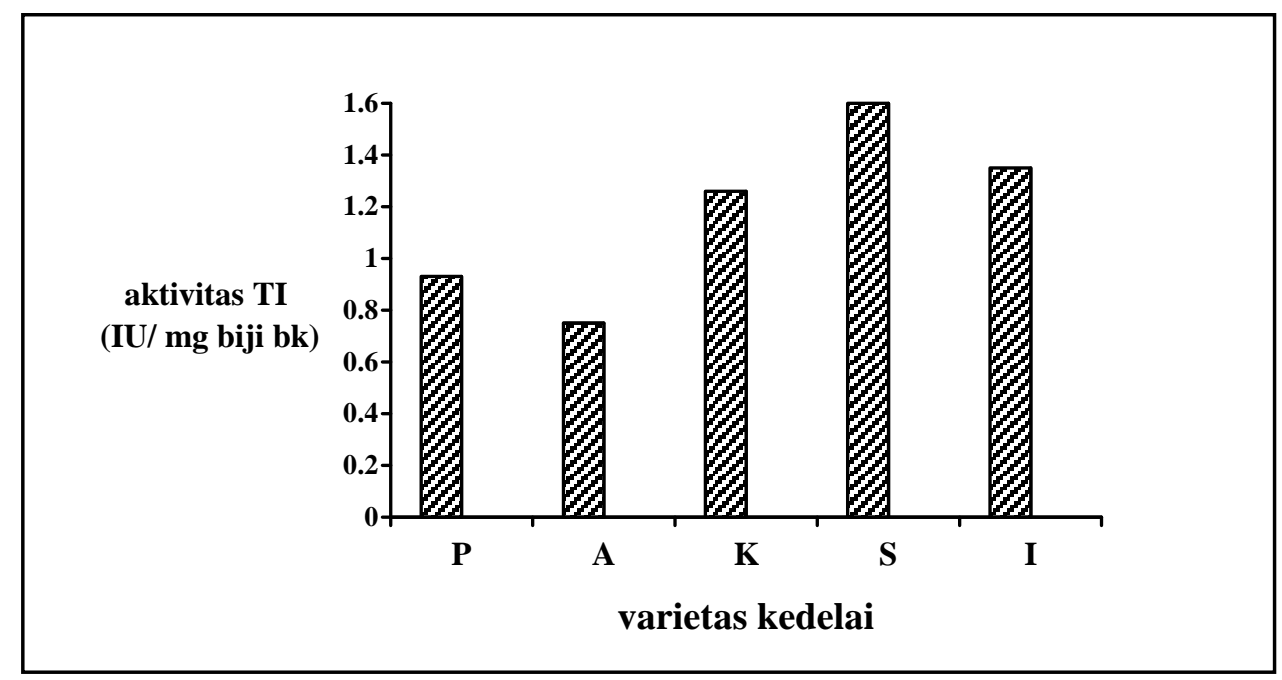

Gambar 1. Aktivitas $\mathrm{TI}$ berbagai varietas kedelai ( $\mathrm{P}=$ Paderman, $\mathrm{A}=$ Argomulyo, $\mathrm{K}=$ Kaba, S = Sinabung, I = Ijen) 


\section{Kenampakan perkecambahan, rendemen}

Perkecambahan biji kedelai dilakukan terhadap biji varietas terpilih, yaitu Sinabung. Selama perkecambahan dilakukan pengamatan ukuran dan kenampakan kecambah untuk menentukan periode perkecambahan yang didasarkan pada kriteria kecambah pada umumnya atau yang biasa dikonsumsi, yaitu sudah keluar akar tunggal, dan kulit biji sudah pecah namun belum keluar akar cabang dan calon daun. Berdasarkan pengamatan tersebut maka perkecambahan biji kedelai dilakukan sampai usia 72 jam. Perkecambahan selama lebih dari 72 jam menghasilkan kecambah yang tidak sesuai dengan kriteria, yaitu sudah keluar akar cabang. Ukuran dan kenampakan kecambah terlihat pada Gambar 2. Kecambah yang diperoleh selanjutnya dikeringkan dan ditepungkan, serta diekstraksi crude TI. Pengujian kadar air kecambah dan tepung digunakan untuk menghitung rendemen berdasarkan berat padatan, hasilnya seperti terlihat pada Tabel 4. Data rendemen digunakan untuk menghitung aktivitas TI selama perkecambahan terhadap berat kering biji.

Selama perkecambahan terjadi penurunan berat padatan (susut berat solid) yang ditunjukkan dengan penurunan rendemen kecambah (Tabel 4). Susut berat tersebut disebabkan selama perkecambahan terjadi pembongkaran cadangan makanan menjadi senyawa sederhana khususnya pati menjadi glukosa. Glukosa digunakan untuk respirasi yang menghasilkan energi, karbondioksida dan air, sehingga selama perkecambahan terjadi peningkatan jumlah air meskipun kemungkinan juga terjadi transpirasi. Air yang terkandung dalam kecambah berasal dari air untuk perendaman biji, kadar air awal biji sebelum dikecambahkan, dan dari proses respirasi.

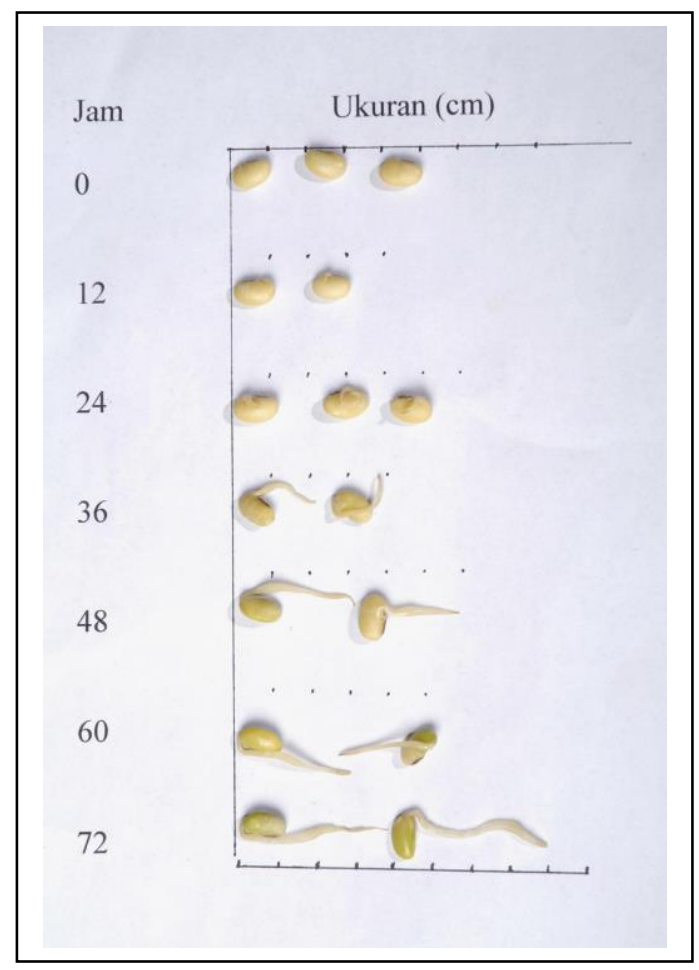

Gambar 2. Kenampakan dan ukuran kecambah kedelai dari berbagai lama perkecambahan 


\section{Aktivitas TI selama perkecambahan biji kedelai varietas terbaik (Sinabung)}

Berdasarkan pengujian statistik menunjukkan bahwa lama perkecambahan berpengaruh terhadap aktivitas TI. Makin lama perkecambahan terjadi kecenderungan aktivitas TI makin menurun, seperti terlihat pada Tabel 5 dan Gambar 3. Penelitian yang dilakukan Alonso et al., (2000) juga menunjukkan bahwa makin lama perkecambahan aktivitas TI makin menurun, perkecambahan sampai 72 jam menyebabkan penurunan aktivitas TI sebesar 25,3\% terhadap aktivitas biji Phaseolus vulgaris. Pada penelitian ini penurunan aktivitas TI sampai perkecambahan 72 jam mencapai $65,6 \%$ terhadap aktivitas biji kedelai yang tidak dikecambahkan.

Penurunan aktivitas TI selama perkecambahan kemungkinan berkaitan dengan fungsi TI dalam biji. Salah satu fungsi TI adalah sebagai pengendali aktivitas proteinase biji (Bewley \& Black, 1983), sehingga untuk memulai terjadi hidrolisis protein kemungkinan diperlukan mekanisme dalam biji untuk meniadakan aktivitas TI. Hidrolisis protein biasanya dimulai sesudah terjadi penurunan cadangan karbohidrat sebagai sumber energi utama perkecambahan (Mayer \& PoljakofMaber, 1989). Pada penelitian ini kemungkinan hidrolisis protein yang besar mulai terjadi sesudah perkecambahan 36 jam, karena aktivitas TI sesudah 36 jam mengalami penurunan yang nyata. Penurunan aktivitas TI tersebut kemungkinan mengakibatkan peningkatan aktivitas proteinase biji, sehingga terjadi peningkatan hirolisis protein. Aktivitas protease meningkat secara tajam sesudah perkecambahan kacang tunggak selama 48 sampai 72 jam (Nnanna \& Phillips, 1988).

Faktor yang berpengaruh terhadap aktivitas TI selama perkecambahan biji, antara lain perubahan konformasi TI dan komposisi asam amino. TI dalam biji berfungsi juga sebagai cadangan protein dalam biji yang larut air (Bewley \& Black, 1983). Hal tersebut memungkinkan protein TI mengalami perubahan selama perkecambahan, misalnya karena hidrolisis yang mengakibatkan perubahan susunan asam amino dan struktur TI. Perubahan ini kemungkinan menyebabkan struktur TI tidak lagi mirip dengan substrat enzim pemecah protein (tripsin), sehingga tidak dapat membentuk kompleks dengan enzim dan terjadi penurunan aktivitas TI. Menurut Whitaker (1997) TI dapat membentuk kompleks dengan enzim tripsin dan menghambat aktivitas enzim memecah substrat karena struktur TI mirip dengan substrat, sehingga pengikatan TI dengan enzim terjadi pada sisi aktif yang sama dengan apabila enzim mengikat substrat protein.

Lama perkecambahan yang dipilih adalah 36 jam jika kecambah akan digunakan sebagai sumber TI untuk komponen makanan fungsional. Pertimbangannya adalah aktivitas TI kecambah yang diperoleh tidak berbeda nyata dibandingkan biji sebelum diinkubasi (perkecambahan 0 jam) dan aktivitas TI kecambah sesudah 36 jam menunjukkan penurunan yang nyata. Pertimbangan yang lain adalah kecambah usia 36 jam sudah memenuhi syarat sebagai kecambah pada umumnya. Perkecambahan selama kurang dari 24 jam belum menghasilkan kecambah sesuai persyaratan kecambah pada umumnya (Gambar 2 ).

Tabel 4. Kadar air dan rendemen dari berbagai lama perkecambahan*

\begin{tabular}{ccccc}
\hline \hline \multirow{2}{*}{$\begin{array}{c}\text { Lama perkecambahan } \\
\text { (jam) }\end{array}$} & \multicolumn{2}{c}{ Kadar air (\%) } & \multicolumn{2}{c}{ Rendemen (g padatan/100g biji bk) } \\
\cline { 2 - 5 } & Kecambah & Tepung kecambah & Kecambah & Crude TI \\
\hline \hline 0 & 65,33 & 7,98 & 99,20 & 0,72 \\
12 & 65,88 & 7,50 & 96,73 & 0,73 \\
24 & 66,05 & 7,64 & 94,67 & 0,78 \\
36 & 66,32 & 7,53 & 89,89 & 0,79 \\
48 & 67,98 & 7,78 & 90,27 & 0,79 \\
60 & 69,95 & 7,25 & 93,51 & 0,77 \\
72 & 71,21 & 7,44 & 91,88 & 0,78 \\
\hline \hline
\end{tabular}

* rata-rata dari 2 ulangan percobaan dan 3 ulangan analisis 
Tabel 5. Aktivitas TI selama perkecambahan biji kedelai varietas Sinabung

\begin{tabular}{cc}
\hline \hline Lama perkecambahan (jam) & Aktivitas TI (IU/mg biji bk) \\
\hline \hline 0 & $1,62 \mathrm{~b}$ \\
12 & $1,60 \mathrm{~b}$ \\
24 & $1,66 \mathrm{~b}$ \\
36 & $1,68 \mathrm{~b}$ \\
48 & $1,38 \mathrm{~b}$ \\
60 & $0,62 \mathrm{a}$ \\
72 & $0,59 \mathrm{a}$ \\
\hline \hline
\end{tabular}

Rata-rata dari 2 ulangan percobaan dan 3 ulangan analisis, notasi huruf yang sama di belakang angka pada kolom yang sama menunjukkan tidak berbeda nyata.

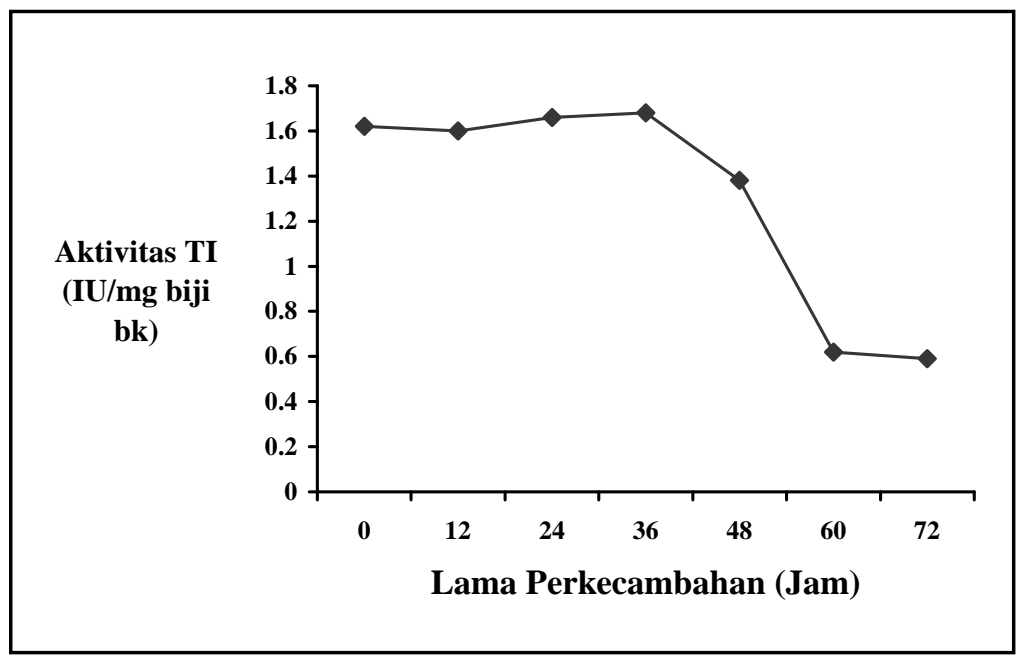

Gambar 3. Aktivitas TI selama perkecambahan biji kedelai varietas Sinabung

\section{Kesimpulan}

Dari hasil penelitian ini dapat disimpulkan bahwa varietas kedelai yang mengandung aktivitas TI tertinggi adalah Sinabung. Selama perkecambahan kedelai tersebut terjadi perubahan aktivitas TI. Perkecambahan kedelai sesudah 36 jam terjadi penurunan aktivitas TI yang nyata. Lama perkecambahan terbaik adalah 36 jam, karena kecambah yang dihasilkan sudah sesuai dengan kriteria kecambah pada umumnya dan aktivitas TI-nya tidak berbeda nyata dengan biji kedelai. Hasil penelitian ini bisa digunakan sebagai bahan pertimbangan dalam memanfaatkan kecambah kedelai sebagai sumber protein dengan kandungan TI yang tinggi untuk pengembangan makanan fungsional.

\section{Ucapan Terima Kasih}

Penulis menyampaikan terima kasih kepada PT Indofood Sukses Makmur bogasari flour mills yang telah memberikan bantuan dana penelitian ini yang merupakan bagian dari penelitian untuk pengembangan tepung terigu bagi penderita diabetes dengan memanfaatkan ekstrak protein kecambah kedelai melalui program Bogasari Nugraha tahun 2004.

\section{Daftar Pustaka}

Anonim. 2004. Spesifikasi Benih Kedelai. BALITKABI, Malang.

Alonso, R., Aguirre, A. and Marzo, F. 2000. Effects of Extrusion and Traditional Processing Methods on Antinutrients and in Vitro Digestibility of Protein and Starch in Faba and Kidney Beans. Food Chem. 68:159-165. 
Bayu-Kanetro dan Wariyah. 2002. Perubahan Sifat Kimia dan Aktivitas Lipoksigenase Kacangkacangan Selama Perkecambahan. Buletin Agroindustri 11: 34-43.

Bewley, J.D. and Black, M. 1983. Physiology and Biochemistry of Seeds in Relation to Germination Vol 1. Springer-verlag, Berlin, Heidelberg, New York.

Frokier, H., Jorgensen, T.M.R., Rosendal, A., Tonsgaard, M.C. and Barkholt, V. 1997. Antinutrional and Allergenic Proteins. In: Shahidi, F. (Eds.). Antinutrient and Phytochemical in Food. American Chemical Society, Washington DC.

King, R.D. and Puwastien, P. 1987. Effect of Germination on Proximate Composition and Nutritional Quality of Winged Bean. J. Food Sci. 52: 106108.

Liu, K. 1999. Soybeans: Chemistry, Technology, and Utilization. Aspen Publ., Inc. Gaithersburg, Maryland.

Losso, J.N. 2002. Preventing Degenerative Diseases by Anti-angiogenic Functional Foods. Food Tech. 56 (6): 78-88.

Mayer, A.M. and Poljakoff, A. 1989. The Germinantion of Seed. Pergamon Press, Oxford.

Nnanna, L.A. and Phillips, R.D. 1988. Change in Oligosacharides Content, Enzyme Activities, and Dry Matter during Controlled Germination of Coapeas. J. Food Sci. 53: 1782-1786
Rackis, J.J. and Gumbmann, M.R. 1981. Protease Inhibitors: Physiological Properties and Nutritional Significance In: Ory, R.L. (Eds.). Antinutrients and Natural Toxicants in Foods, Food and Nutrition Press, Inc., Westport, Connecticut.

Saini, H.S. 1989. Activity and Thermal Inactivation of Protease Inhibitors in Grain Legumes In: Huisman, J., van der Poel, T.F.B. dan Liener, I.E. (Eds.). Recent Advances of Research in Antinutritional Factors in Legume Seeds. Pudoc Wageningen.

Su, G. and Chang, K.C. 2002. Trypsin Inhibitor Activity in Vitro Digestibility and Sensory Quality of Meat-like Yuba Products as Affected by Processing. J. Food Sci. 67: 1260-1266.

Sutardi. 1996. Perubahan Kadar Vitamin E, B1, dan Karoten Selama Perkecambahan Beberapa Kacang-kacangan. Laporan penelitian F.TP UGM, Yogyakarta.

Whitaker, J.R. 1997. Protease and Alpha-Amilase Inhibitors of Higher Plants. In: Shahidi, F. (Eds.). Antinutrients and Phytochemicals in Food. American Chem. Society, Woshington, DC.

Zuheid-Noor, Marsono, Y. dan Mary-Astuti. 2000. Sifat Hipoglisemik Komponen Kedelai. Prosiding Seminar Nasional Industri Pangan Vol II PATPI, Surabaya. 